\title{
Analisis Kompetensi Guru dalam Mempersiapkan Media Pembelajaran Berbasis Teknologi Informasi Era Revolusi Industri 4.0
}

\author{
Fanny Rahmatina Rahim ${ }^{1)}$, Dea Stevani Suherman ${ }^{2)}$, Murtiani ${ }^{1}$ \\ ${ }^{1)}$ Staf Pengajar Jurusan Fisika, FMIPA Universitas Negeri Padang \\ ${ }^{2}$ Staf Pengajar Jurusan PGSD, FIP Universitas Negeri Padang \\ fannyrahmatina@fmipa.unp.ac.id
}

\begin{abstract}
Indonesia faces the biggest challenge in education. Various problems have arisen including teachers not yet utilizing technology optimally in learning. Teachers in schools still maintain conventional learning. Actions to motivate teachers are needed so that integrated learning of information technology can be implemented well. This is in accordance with the demands of the industrial revolution 4.0 in the learning process where teachers and students together make innovations including the use of information technology-based learning media. To find out how deep the teacher's understanding of the preparation of information technology-based learning media in the revolution era 4.0, analysis in the form of quantitative data presented descriptively is needed.
\end{abstract}

Keywords : kompetensi guru, media pembelajaran, teknologi informasi, revolusi industri 4.0

This is an open access article distributed under the Creative Commons 4.0 Attribution License, which permits unrestricted use, distribution, and reproduction in any medium, provided the original work is properly cited. $\odot 2019$ by author and Universitas Negeri Padang.

\section{PENDAHULUAN}

Tujuan utama dari pendidikan adalah mencipta (Rahim, 2019a). Hal penting yang harus diciptakan oleh pendidikan adalah keberhasilan pembangunan. Hal ini dapat dilakukan dengan menerapkan learning to know, learning to do, learning to be, dan learning to live together dalam setiap proses belajar mengajar (Rahim, 2019b).

Keberhasilan pembangunan tercermin dalam sumber daya manusia yang berkualitas. Keberhasilan pembangunan mencakup pengembangan potensi diri meliputi kekuatan spiritual keagamaan, pengendalian diri, kepribadian, kecerdasan, akhlak mulia, serta keterampilan yang diperlukannya (UU No. 20 Tahun 2003). Adanya pendidikan menimbulkan hasrat dalam diri seseorang untuk berlombalomba dan memotivasi diri kita untuk lebih baik dalam segala aspek kehidupan.

Indonesia membutuhkan inovasi dalam aspek pendidikan. Salah satunya adalah pemanfaatan teknologi informasi untuk menunjang keberhasilan kebaruan strategi dan teknik pembelajaran (Suryadi, 2007). Pendidikan yang mengikuti perkembangan zaman menjadi faktor penentu dalam keberhasilan masyarakat. Hal inilah yang memicu terjadinya perubahan sosial sehingga menjadi bahan kajian agar dapat mempersiapkan siswa menghadapi tantangan abad ke-21.

Tantangan terbesar saat ini adalah kemampuan siswa untuk bersaing dalam dunia IPTEKS dengan negara lain. Memasuki revolusi industri 4.0 yang dikenal dengan zaman milenial menuntut sistem pendidikan berbenah diri dari segala aspek, mulai dari manajemen, metode, dan strategi pembelajaran serta media yang digunakan dalam proses pembelajaran (Suwardana, 2017). Revolusi industri 4.0 menuntut proses pembelajaran yang merupakan bagian dari kurikulum (Rahim, 2017) untuk beralih dari pembelajaran konvensional menuju pembelajaran yang memanfaatkan teknologi informasi. Perkembangan dunia maya membe rikan perubahan besar dalam dunia pendidikan. Bernett Berry menyatakan bahwa fenomena saat ini diakibatkan oleh kemajuan teknologi digital. Teknologi digital telah terbukti membuat transfer informasi menjadi lebih efisien (Hosnan, 2014).

Teknologi digital semakin umum digunakan (Hasanah, 2015). Kemajuan teknologi digital dan informasi dapat digunakan dalam menfasilitasi perkembangan pendidikan (Divayana, 2016 dan Sugiharni, 2018). Oleh karena itu, dibutuhkan inovasi yang pesat dalam dunia pendidikan dan menjadi prioritas utama 
dalam pengembangan sistem pendidikan terutama dalam pembuatan media pembelajaran. Media pembelajaran memiliki kedudukan penting dalam sebuah perencanaan pembelajaran. Proses perencanaan pembelajaran diawali dengan perumusan tujuan instruksional khusus sebagai pengembangan dari tujuan intruksional umum. Agar tujuan pembelajaran dapat tercapai, perlu adanya penggunaan alat bantu pembelajaran yang tepat dan sesuai dengan karakteristik siswa.

Media pada hakekatnya merupakan salah satu komponen sistem pembelajaran. Menjadi sebuah komponen, media hendaknya merupakan bagian integral dan harus sesuai dengan proses pembelajaran secara menyeluruh. Ujung akhir dari pemilihan media adalah penggunaaan media tersebut dalam kegiatan pembelajaran, sehingga memungkinkan siswa dapat berinteraksi dengan media yang dipilih.

Media pembelajaran merupakan sarana komunikasi (Sanjaya, 2006) yang digunakan untuk menyampaikan pesan dalam pembelajaran agar siswa sebagai penerima pesan tidak salah menangkap isi pesan berupa materi pembelajaran (Hidayatullah, 2016). Media bertujuan untuk meningkatkan kinerja dan memungkinkan berbagai kegiatan dapat dilaksanakan dengan cepat, tepat, dan akurat (Hamzah, 2011). Selain itu, bahan yang ditampilkan dalam media pembelajaran dapat menarik minat siswa dan meningkatkan pemahaman siswa melalui bahan yang ditampilkan (Nuroifah, 2015).

Media memegang peranan penting dalam proses pembelajaran. Media memiliki dua peran utama, yaitu: sebagai alat bantu mengajar dan sebagai sumber belajar yang dapat digunakan secara mandiri oleh siswa. Media sebagai alat bantu mengajar disebut dependent media dan media sebagai sumber belajar siswa disebut independent media (Rusman, 2012: 60).

Arsyad (2002) menyatakan bahwa media pembelajaran dapat meningkatkan proses belajar siswa sehingga hasil belajar siswa menjadi lebih baik. Meningkatnya proses belajar siswa terlihat dari bangkitnya motivasi dan rangsangan kegiatan belajar yang membawa pengaruh psikologis siswa. Ada beberapa manfaat yang dirasakan guru dan siswa jika digunakan di dalam proses pembelajaran. Manfaat yang dirasakan oleh siswa, yaitu: (1) pembelajaran menjadi lebih menarik sehingga mendapatkan perhatian dari siswa, (2) materi pembelajaran lebih mudah dipahami siswa karena memiliki makna yang lebih jelas, (3) metode pembelajaran memungkinkan siswa untuk menguasai materi lebih baik, (4) metode pembelajaran menjadi lebih bervariasi, tidak semata-semata hanya komunikasi verbal melalui penuturan kata-kata lisan guru, dan (5) siswa belajar lebih banyak melakukan kegiatan belajar, sebab tidak hanya mendengarkan penjelasan dari guru saja, tetapi juga aktivitas lain yang dilakukan seperti mengamati, melakukan, mendemonstrasikan dan lain-lainya.

Manfaat media pembelajaran bagi guru, yaitu: (1) memberikan pedoman, arah untuk mencapai tujuan, (2) menjelaskan struktur dan urutan pengajaran dengan baik, (3) memberikan kerangka sistematis secara baik, (4) memu dahkan guru menyampaikan materi pembela jaran, (5) membantu kecermatan dan ketelitian guru dalam penyajian dalam pembelajaran, (6) membangkitkan rasa percaya diri seorang guru, dan (7) meningkatkan kualitas pembelajaran.

Saat ini, dari 2,7 guru yang ada di Indonesia, hanya $10 \%$ hingga $15 \%$ yang memanfaatkan teknologi dalam pembelajaran di kelas. Angka ini menunjukkan nilai yang sangat minim mengingat perkembangan teknologi sudah begitu pesat. Padahal, penggunaan media pembelajaran di kelas sangat direkomendasikan untuk meningkatkan kualitas pembelajaran. Media pembelajaran membuat siswa dapat berinteraksi secara langsung dengan materi pembelajaran yang sesuai dengan kemampuan dan minat siswa (Fadli, 2017).

Pembelajaran merupakan bagian penting dalam impelementasi kurikulum (Rahim, 2018). Menurut paradigma pembelajaran tradisional, proses belajar mengajar biasanya berlangsung di dalam kelas. Guru memiliki peran yang dominan sehingga harus bertanggung jawab terhadap efektivitas proses belajar mengajar. Oleh karena itu, guru menjadi sumber belajar utama. Namun, adanya pergeseran konsep pembelajaran menyebabkan dominasi guru berkurang dan sebagian besar hanya berperan sebagai fasilitator dan bukan sebagai satu-satunya sumber belajar. Sebagai fasilitator, guru semestinya dapat memfasilitasi siswa agar dapat belajar di mana saja dan kapan saja siswa merasa memerlukan.

Guru merupakan pilar utama dalam sistem pendidikan nasional (Rahim, 2017). Guru sebagai sosok kepemimpinan transformasional yang menstimulasi secara intelektual (Budiwibowo, 2014) dalam menjalankan tugas 
kependidikannya harus memiliki keterampilan dalam dunia teknologi. Dengan adanya persaingan global, teknologi semakin menguasai dunia. Berbagai masalah fundamental yang dihadapi pendidikan nasional saat ini tercermin dalam realitas pendidikan yang dijalani. Dalam konteks metode dan strategi pembelajaran di sekolah-sekolah, sebagian besar guru di sekolah masih kurang kreatif dan inovatif karena masih memakai metode dan strategi yang konservatif (Suyanto, 2006). Selayaknya para guru sudah membaca kondisi zaman yang sangat dinamis, sehingga luaran pendidikan sudah memiliki mental yang bersifat mandiri, pemikiran kritis dan kreatif. Pemikiran kritis dan kreatif adalah kunci sukses bagi siswa dalam mencapai keberhasilan akademis.

Pemikiran kritis dan kreatif dapat melatih siswa untuk mengembangkan penguasaan teknologi. Teknologi sebagai gerbang modernisasi dan kemajuan suatu bangsa menggiring siswa untuk meningkatkan keterampilan proses sains (Permanasari, 2016). Untuk dapat merancang kegiatan pembelajaran seperti yang diharapkan diperlukan guru yang memiliki kompetensi dan penguasaan yang baik di bidang teknologi.

Guru dituntut mampu memanfaatkan teknologi dalam pembelajaran. Menurut Peraturan Menteri Pendidikan Nasional Nomor 16 Tahun 2007 Tentang Standar Kualifikasi Akademik dan Kompetensi Guru dijelaskan bahwa guru harus memanfaatkan teknologi informasi dan komunikasi untuk kepentingan pembelajaran. Dalam Peraturan Pemerintahan Republik Indonesia Nomor 74 Tahun 2008 tentang Guru pasal tiga ayat empat menyatakan bahwa kompetensi pedagogik yang harus dikuasai guru dalam pengelolaan pembelajaran peserta didik yang salah satunya adalah pemanfaatan teknologi pembelajaran.

Adanya peraturan menteri tentang kompetensi yang harus dimiliki guru, maka penggunaan teknologi informasi dan komunikasi seharusnya benar-benar diaplikasikan pada proses pembelajaran untuk mencapai tujuan belajar. Lain hal jika kondisi tidak memungkinkan untuk siswa menggunakan teknologi, guru dapat mengalihkan ke penggunaan media pembelajaran akternatif.

Pemerintah telah berupaya untuk meningkatkan kualitas guru di bidang teknologi dengan menyempurnakan Kurikulum 2013. Kurikulum yang sedang digunakan saat ini menuntut siswa dan guru bersama-sama mengembangkan kompetensi terutama untuk menjawab tantangan global. Namun, usaha ini belum maksimal karena guru belum memaksimalkan pemanfaatan teknologi dalam proses pembelajaran.

SMAN 2 Palembayan merupakan sekolah yang baru berdiri pada tahun 2017 yang berlokasi di Kecamatan Palembayan, Kabupaten Agam. Saat ini, sebagian besar guru didominasi oleh pendidik yang baru bertugas selama kurang dari 2 tahun. Total guru yang berdinas di sekolah ini adalah 20 orang yang terdiri dari 5 guru laki-laki dan 15 guru perempuan.

Berdasarkan hasil observasi dan wawancara yang dilakukan pada guru SMAN 2 Palembayan, pembelajaran di sekolah kebanyak kan masih bersifat konvensional dengan memanfaatkan sarana papan tulis sebagai media. Sebagian besar guru juga masih belum mampu menggunakan teknologi yang bervariasi untuk menyampaikan materi. Siswa pun masih menggunakan bahan ajar cetak yang disediakan sekolah dalam proses pembelajaran. Bahkan pada beberapa mata pelajaran, guru meminta siswa untuk menggunakan buku secara bergantian.

Akar dari permasalahan ini adalah guru belum mempersiapkan diri dengan matang menghadapi perubahan zaman. Kurangnya pengalaman guru secara intensif untuk memanfaatkan teknologi dalam pembelajaran menjadi salah satu faktor. Tidak terlalu banyak variasi media pembelajaran yang diketahui guruguru. Padahal ada banyak sekali media pembelajaran baik offline maupun online yang dapat dimanfaatkan guru di kelas. Pengaplikasiaannya pun tidak terlalu sulit, asalkan guru mau meluangkan waktu untuk mengikuti pelatihan. Setelah guru menguasai program tersebut, guru akan terbiasa dan merasakan kemudahan dalam penggunaannya.

Salah satu program yang dapat membantu guru-guru dalam mempersiapkan media pembelajaran adalah aplikasi Kvisoft Flipbook Maker (KFM). Aplikasi KFM dapat membantu guru menyajikan materi pembela jaran secara lebih kreatif dan variatif. Ketersediaan bahan ajar yang terbatas di sekolah pun dapat dipenuhi karena sebagian siswa sudah mampu menggunakan komputer. Selain itu, sebagian besar guru di SMAN 2 Palembayan adalah guru yang mampu mengembangkan diri dibidang IT. 
Aplikasi KFM merupakan sebuah software untuk mengkonversi file pdf ke tampilan buku seperti halaman bolak-balik (dapat dilihat pada Gambar1). Dengan menggu nakan program ini, bahan ajar yang sebelumnya tidak terlalu menarik karena dalam format pdf menjadi lebih menarik yang dilengkapi dengan animasi dan video (Seamardi, 2016).

Menurut Hidayatullah (2016), KFM adalah aplikasi untuk membuat e-book, e-modul, e-paper dan e-magazine. Tidak hanya berupa teks, pada aplikasi ini dapat disisipkan gambar, grafik, suara, link dan video pada lembar kerja. Secara umum, perangkat multimedia ini dapat memasukkan file berupa pdf, gambar, video dan animasi sehingga dapat dibuat menjadi lebih menarik. Selain itu, aplikasi ini memiliki desain template dan fitur seperti background, tombol kontrol, bar navigasi, hyperlink dan backsound. Siswa dapat membaca seperti layaknya membuka buku secara fisik karena terdapat efek animasi dimana saat berpindah halaman akan terlihat seperti membuka buku secara fisik.

Hasil akhir bisa disimpan ke format html, exe, zip, screen saver dan app seperti yang diungkapkan oleh Mulyaningsih dan Saraswati (2017) bahwa KFM dirancang untuk mengkonversi file PDF ke halaman balik publikasi digital atau digital book. Perangkat lunak ini dapat mengubah tampilan file PDF menjadi lebih menarik seperti layaknya sebuah buku. Selain itu KFM juga dapat membuat file PDF menjadi seperti sebuah majalah, majalah digital, flipbook, katalog perusahaan, katalog digital dan lain-lain. Sugianto, Abdullah, Elvyanti, dan Muladi (2013: 104), menyatakan bahwa pada aplikasi KFM dapat ditambahkan file-file gambar, pdf, swf, dan file video berformat FLV dan MP4. Sedangkan keluaran atau output dari software ini dapat berupa HTML, EXE, ZIP, dan APP. Output TI Flash membalik buku sebagai format HTML yang memungkinkan untuk mengupload ke website untuk dilihat secara online. Output sebagai berdiri sendiri EXE untuk pengiriman CD. Paket itu sebagai format ZIP untuk email cepat. Output berupa APP dapat digunakan di I-Phone, Tablet, I-Pad, dan lain-lain.

Melalui aplikasi ini, guru dapat mengubah tampilan buku yang membosankan menjadi lebih menarik dan variatif. Ketertarikan siswa bertambah terhadap materi pembelajaran karena buku yang tersedia dilengkapi dengan animasi, video, audio, dan gambar yang dapat mendukung pembentukan kemampuan berpikir kritis dan kreatif siswa. Penggunaan aplikasi KFM juga tidak terlalu sulit. Guru hanya perlu mempersiapkan bahan ajar dan tambahan fitur interaktif yang dapat digabung menjadi satu media.

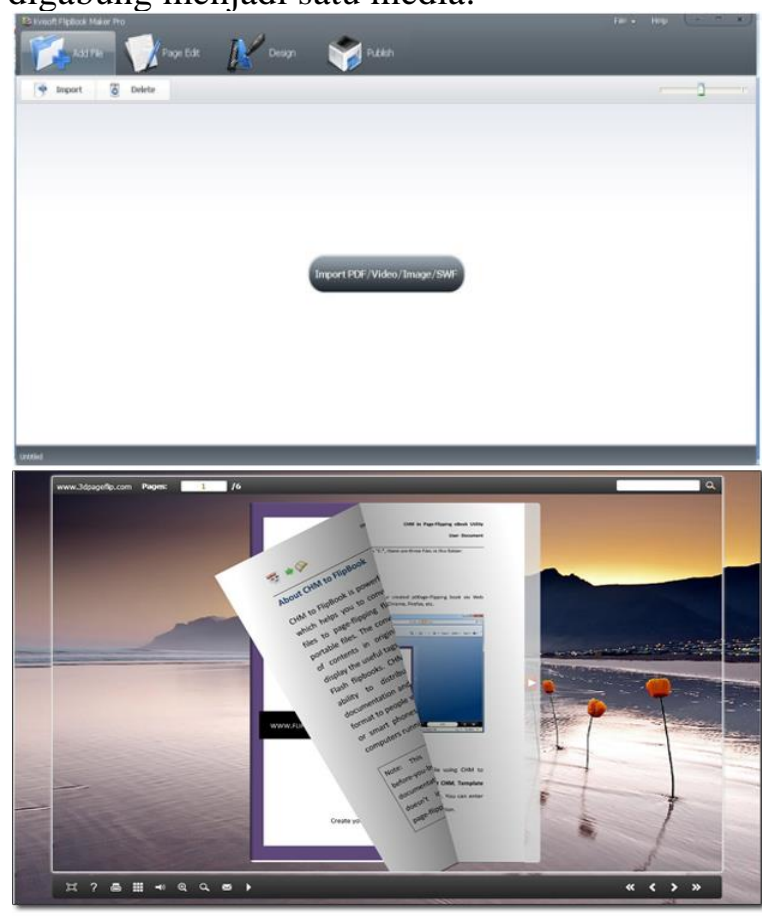

Gambar 1. Tampilan Aplikasi (atas) dan Output (bawah) Aplikasi KFM

Mempersiapkan media pembelajaran interaktif merupakan suatu kewajiban yang harus dilakukan guru. Untuk itu, guru perlu mengevaluasi kemampuan diri yang dibutuh kan seorang guru untuk mengembang kan media pembelajaran. Ada beberapa hal yang perlu dilakukan oleh guru, diantaranya adalah menganalisis kemampuan penggunaan IT dan komputer serta mengenal berbagai macam multimedia.

Berdasarkan penjabaran masalah yang ditemukan di lapangan, penulis merasa perlu untuk melakukan analisis kompetensi guru dalam mempersiapkan pembelajaran berbasis teknologi informasi era revolusi 4.0.

\section{METODE PENELITIAN}

Metode penelitian yang digunakan adalah penelitian deskriptif dengan pendekatan kuantitatif. Metode penelitian ini menurut Sugiyono (2012: 8) yaitu metode yang digunakan untuk meneliti populasi atau sampel tertentu, pengumpulan data menggunakan instrumen penelitian, analisis data bersifat kuantitatif, dengan tujuan menguji hipotesis 
yang telah ditetapkan. Objek penelitian ini adalah guru-guru di SMAN 2 Palembayan.

Data yang digunakan dalam penelitian ini adalah data yang bersifat kuantitatif karena dinyatakan dengan angka-angka yang menunjukkan nilai terhadap besaran atas variabel yang diwakilkannya. Jenis data yang digunakan dalam penelitian ini adalah data primer. Data primer merupakan data yang diperoleh secara langsung dari objek yang diteliti. Data primer diperoleh dari angket dan hasil penilaian peneliti terhadap produk yang telah dikerjakan oleh guru-guru di SMAN 2 Palembayan. Data hasil penilaian menjadi data kompetensi guru dalam mempersiapkan pembelajaran berbasis teknologi informasi.

Teknik pengumpulan data dalam penelitian ini yaitu angket dan lembar penilaian. Angket adalah teknik pengumpulan data yang dilakukan dengan cara memberikan seperangkat pertanyaan atau pernyataan tertulis kepada responden (Sugiyono, 2011). Angket berisi pertanyaan seputar pengalaman guru dalam mempersiapkan media pembelajaran. Sedangkan lembar penilaian terdiri dari indikator untuk menilai produk kegiatan Bimtek.

Teknik pengolahan data pada angket meliputi kegiatan editing, coding, tabulasi, dan scoring (Misbahudin, 2013: 32). Editing dalam penelitian ini yaitu mengoreksi angket penelitian yang telah disebar. Coding yaitu memberikan kode terhadap angket yang akan dianalisis, dari 18 angket yang telah disebar diberikan angka 118 yang membedakan jawaban dari tiap responden. Tabulasi yaitu jawaban dari angket yang telah disebar dimasukkan ke dalam tabel sesuai dengan analisis. Scoring yaitu jawaban dari pertanyaan yang terdapat dalam angket dianalisis dengan menggunakan 2 kategori (YaTidak, Sudah-Belum). Teknik pengolahan data dari hasil lembar penilaian menggunakan 6 indikator yang kemudian dirata-ratakan.

\section{HASIL DAN PEMBAHASAN}

Berdasarkan angket yang telah diberikan kepada 18 orang guru, didapatkan data bahwa semua guru di SMAN 2 Palembayan belum mengetahui aplikasi KFM. Mengenai jumlah guru yang pernah membuat media pembelajaran, SMAN 2 Palembayan memiliki 12 dari 18 orang guru yang pernah membuat media pembelajaran. Dari 12 guru tersebut, 4 orang diantaranya membuat media pembelajaran berbasis IT sedangkan sisanya masih konvensional. Data ini menunjukkan bahwa pemanfaatan IT dalam pembelajaran masih rendah.

Pemanfaatan media pembelajaran berbasis teknologi informasi memang sangat bagus diterapkan di sekolah. Namun ada beberapa kendala yang dihadapi oleh guru di SMAN 2 Palembayan. Kendala tersebut meliputi aspek sarana dan prasarana, aspek siswa, dan aspek guru.

Dari aspek sarana dan prasarana, sekolah masih belum memiliki proyektor yang cukup untuk digunakan dalam waktu yang bersamaan. Proyektor yang dimiliki sekolah hanya 3 buah. Dalam satu sesi pembelajaran, hanya 3 kelas yang dapat menggunakan proyektor.

Dari aspek siswa, masih banyak siswa yang belum memanfaatkan komputer sebagai media belajar dan informasi. Sebagian siswa yang dapat mengoperasikan komputer hanya memanfaatkan komputer untuk hiburan seperti bermain game online. Begitu juga dengan pemanfaatan handphone yang hanya sebagai media komunikasi dan hiburan, bukan untuk mencari bahan belajar.

Dari aspek guru, masih ada guru yang belum memiliki komputer. Sebagian guru masih belum mengetahui sepenuhnya tentang media pembelajaran berbasis IT. Ada juga guru yang masih terbatas dari segi waktu dan keterampilan untuk membuat media pembelajaran.

Berdasarkan pendapat yang dikemukakan oleh guru-guru di SMAN 2 Palembayan, Pemerintah belum sepenuhnya meningkatkan kualitas guru dalam bidang teknologi walaupun sudah banyak kegiatan untuk meningkatkan kualitas guru. Sebagian besar kegiatan peningkatan kompetensi guru di bidang teknologi masih terfokus pada guru-guru di perkotaan, sedangkan di pedesaan masih kurang.

Peningkatan kompetensi penggunaan teknologi informasi guru tidak hanya menunggu turun tangan dari pemerintah. Bimbingan teknis dapat dilakukan guna mencapai tujuan spesifik. Salah satunya kegiatan Bimtek yang dilakukan oleh tim Program Kemitraan Masyarakat (PKM) UNP guna melatih guru-guru di SMAN 2 Palembayan untuk mempersiapkan media pembelajaran berbasis teknologi informasi melalui aplikasi Kvisoft Flipbook Maker (KFM).

Bimtek dilaksanakan sebanyak 3 tahap yang terdiri dari 2 tahap untuk orientasi dan praktek terbimbing dan 1 tahap untuk praktek mandiri. Kegiatan pada tahap pertama adalah pembahasan mengenai media pembelajaran 
berbasis IT dan cara penggunaan aplikasi KFM. Kegiatan pada tahap kedua adalah praktek yang dibimbing langsung oleh tim PKM.

Saat melakukan kegiatan Bimtek, guruguru menunjukkan ketertarikan yang positif. Menurut penuturan guru-guru, aplikasi ini dapat efektif digunakan di dalam kelas terutama untuk mata pelajaran yang membutuhkan banyak demonstrasi dan peraga seperti Fisika. Hal ini dikarenakan aplikasi KFM dilengkapi dengan multimedia seperti audio, video, dan animasi. Materi pembelajaran menjadi lebih jelas dan menarik untuk dipelajari oleh siswa.

Setelah dibekali ilmu mengenai aplikasi KFM, guru-guru di SMAN 2 Palembayan mela kukan praktek terbimbing pembuatan media pembelajaran sesuai dengan mata pelajaran yang diampu. Media pembelajaran berbasis aplikasi KFM tidak hanya bersumber dari bahan ajar, tetapi juga media presentasi atau kumpulan gambar dan video. Cuplikan media pembela jaran yang telah diselesaikan oleh guru-guru di SMAN 2 Palembayan seperti pada Gambar 2.

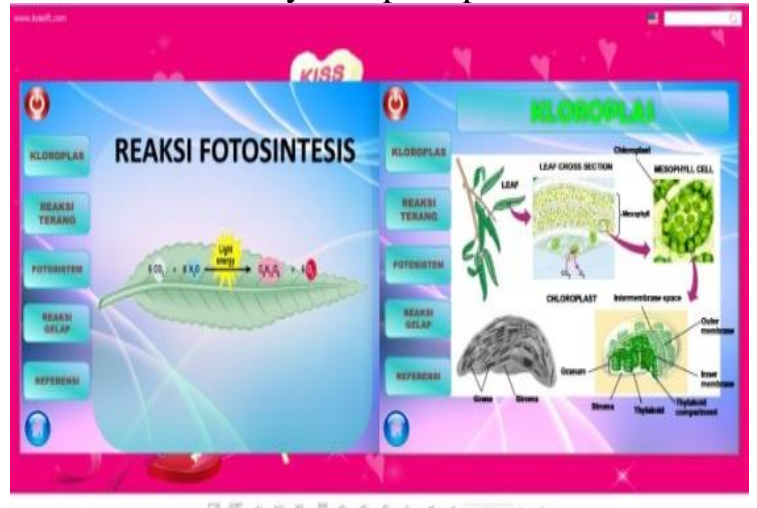

Gambar 2. Cuplikan Media Pembelajaran Rancangan Guru di SMAN 2 Palembayan

Media pembelajaran yang telah diselesai kan oleh guru dinilai oleh tim PKM sebagai bukti sejauh mana tingkat pemahaman guru dalam mengikuti Bimtek. Aspek penilaian yang diberikan meliputi: 1) penggunaan huruf (jenis, warna, dan ukuran), 2) tampilan layout, 3) penggunaan ilustrasi, gambar, atau foto, 4) penggunaan video, 5) pengaplikasian navigation $k e y, 6)$ pengaplikasian audio. Rincian penilaian tiap aspek dapat dilihat pada Gambar 3.

Aspek audio menjadi aspek paling rendah dibandingkan dengan yang lain. Sebagian besar guru tidak menggunakan audio dalam pembelajaran kecuali untuk guru bahasa (bahasa inggris dan bahasa indonesia). Aspek yang memiliki nilai paling tinggi adalah navigasi.
Penggunaan navigasi sudah maksimal meliputi icon play, next, previous, first page, last page, bookmark, table of content, print, share, dan lain-lain.

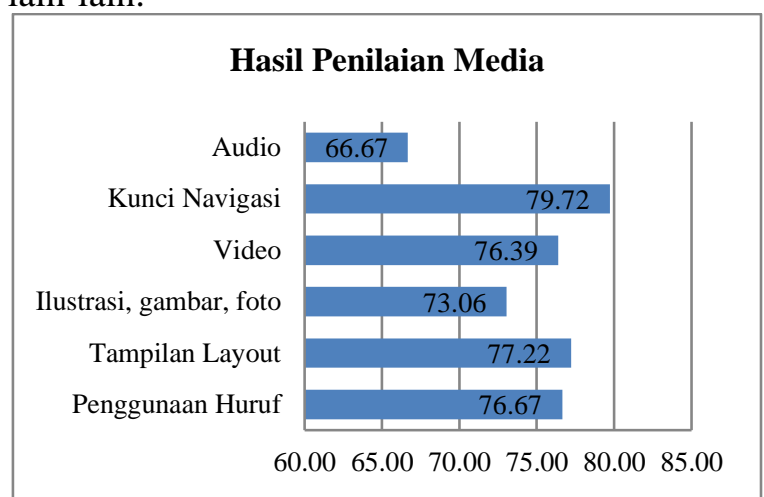

Gambar 3. Hasil penilaian media yang telah dikembangkan oleh guru-guru SMAN 2 Palembayan

Rata-rata skor yang diterima oleh peserta bimtek adalah 75. Skor tersebut menunjukkan pelakasanaan bimtek di SMAN 2 Palembayan sudah berjalan dengan cukup baik. Namun ada beberapa hal yang harus menjadi evaluasi dalam kegiatan ini. Pertama, guru-guru perlu memiliki kemampuan IT yang baik. Beberapa guru masih belum memahami sepenuhnya penggunaan microsoft office yang menjadi dasar dalam pembuatan media pembelajaran interaktif menggunakan aplikasi KFM. Kedua, guru perlu membekali diri dengan konsep pengembangan media pembelajaran.

Tujuan seorang guru mengembangkan media pembelajaran antara lain untuk mendemonstrasikan, memberikan gambaran atau penjelasan tentang materi secara lebih rinci, dan mempermudah siswa menerima materi dengan logika. Dasar pertimbangan untuk mengembangkan media adalah terpenuhinya kebutuhan siswa dan tercapainya tujuan yang diinginkan dalam penggunaan media pembelajaran. Untuk itu, ada beberapa kompetensi yang perlu dimiliki seorang guru sebelum mengembangkan media pembelajaran.

Kompetensi pertama yang harus dimiliki guru sebelum merancang media pembelajaran berbasis IT adalah mengumpulkan sumber belajar atau bahan ajar yang berkualitas. Kualitas bahan ajar yang baik terlihat dari konten bahan ajar dan kemasan penyajiannya, sehingga bahan ajar dapat berkualitas dan menarik minat siswa untuk mempelajari/ membacanya. Bahan ajar dikatakan berkualitas apabila konten yang dibahas dalam bahan ajar tersebut memberikan pengetahuan dan informasi 
yang mendalam dan bermanfaat bagi siswa, serta dibuat mengikuti aturan-aturan/kaidah legalitas suatu bahan ajar (Divayana, 2018).

Agar konten bahan ajar dapat berkualitas, seorang guru perlu membuat bahan ajar sendiri yang sesuai dengan kebutuhan siswa. Selain ditulis sendiri, guru dapat berkolaborasi dengan guru lain untuk menulis bahan ajar secara kelompok, dengan guru-guru bidang studi sejenis, baik dalam satu sekolah atau tidak. Penulisan juga dapat dilakukan bersama pakar, yang memiliki keahlian di bidang ilmu tertentu. Disamping penguasaan bidang ilmu, untuk dapat menulis sendiri bahan ajar, diperlukan kemampuan menulis sesuai dengan prinsipprinsip instruksional.

Penulisan bahan ajar selalu mempertim bangkan kebutuhan siswa, meliputi kebutuhan pengetahuan, keterampilan, bimbingan, latihan, dan umpan balik (Rizki, 2016). Untuk mengetahui seberapa besar kebutuhan siswa terhadap media pembelajaran, guru perlu melakukan analisis pendahuluan. Analisis pendahuluan merupakan langkah awal pengem bangan produk yang terdiri dari analisis kebutuhan dan konteks. Diperlukan instrumen untuk menganalisis kebutuhan, yang mencakup analisis karakteristik peserta didik. Sedangkan analisis konteks mencakup analisis awal-akhir, analisis materi, dan analisis potensi daerah.

Materi bahan ajar berupa pokok bahasan dan sub pokok bahasan yang tercantum dalam program pembelajaran sesuai dengan silabus. Dalam pengemasan materi pembelajaran, guru dapat memanfaatkan informasi yang sudah ada dalam literatur lain. Informasi dikumpulkan berdasarkan kebutuhan. Informasi disusun dengan gaya bahasa yang sesuai dan dapat diberi tambahan kompetensi atau keterampilan yang akan dicapai, bimbingan belajar, latihan, tes, serta umpan balik agar mereka dapat mengukur sendiri kompetensinya yang telah dicapai. Keuntunganya, cara ini lebih cepat diselesaikan dibanding menulis sendiri. Sebaiknya memperoleh ijin dari pengarang buku aslinya.

Kompetensi kedua saat mengembangkan media pembelajaran adalah mengemas media secara menarik. Media dikatakan menarik apabila mampu membuat siswa betah/senang untuk membaca konten yang disajikan. Untuk itu, perlu adanya multimedia yang dipadukan dengan menggunakan aplikasi KFM menjadi sebuah media pembelajaran yang interaktif.
Adanya sarana penyampaian isi bahan ajar menjadi sebuah media pembelajaran interaktif, siswa mendapatkan pengalaman visual antara lain untuk memotivasi belajar, dan memperjelas dan mempermudah konsep yang abstrak, dan mempertinggi daya serap atau retensi belajar. Sebagai bagian dari sistem pembelajaran media mempunyai nilai-nilai praktis berupa kemampuan keterampilan untuk: membuat konkrit konsep yang abstrak, membawa objek berbahaya atau sukar didapat ke dalam lingkungan belajar, menampilkan objek yang terlalu besar, dan, menampilkan objek yang dapat diamati dengan mata telanjang.

Media yang digunakan dalam proses pembelajaran harus disesuaikan dengan tujuan yang ingin dicapai. Jika tujuan pembelajaran bersifat hafalan, maka media yang cocok adalah audio. Jika tujuannya adalah untuk memahami suatu wacana, maka media yang bisa digunakan adalah media cetak. Bila tujuan pembelajaran sifatnya motorik (gerak), media yang digunakan adalah media film dan video. Penggunaan media pembelajaran yang berbasis TIK merupakan hal yang tidak mudah. Penggunaan media tersebut harus memperhatikan beberapa teknik agar media yang dipergunakan dapat dimanfaatkan dengan maksimal.

Sifat unik setiap siswa ditambah lagi dengan lingkungan dan penga laman yang berbeda, sedangkan kurikulum dan materi pendidikan ditentukan sama untuk setiap siswa, maka guru banyak mengalami kesulitan jika semuanya itu harus diatasi sendiri. Masalah ini dapat diatasi dengan memberikan perangsang yang sama, mempersamakan pengalaman, dan menimbulkan persepsi yang sama.

Selain memperhatikan konten dan kemasan media pembelajaran, guru hendaknya memperhatikan prinsip umum dalam membuat media pembelajaran. Menurut Aqib (2013), ada beberapa prinsip umum yang digunakan dalam pembuatan media pembelajaran, yaitu Visible (mudah dilihat), Interesting (menarik), Simple (sederhana), Useful (bermanfaat bagi pelajar), Accurate (benar dan tepat sasaran), Legitimate (sah dan masuk akal), dan Structured (tersusun secara baik, runtut).

Keberhasilan suatu program dapat dilihat dari beberapa aspek diantaranya adalah faktor reactions dan learning (Gomes, 2000). Reactions artinya mengevaluasi suatu program dengan mengukur kepuasan peserta bimtek. Bimtek dikatakan efektif apabila peserta merasa 
senang dan puas dengan materi bimtek. Selama kegiatan bimtek berlangsung, guru-guru mendapatkan banyak ilmu baru sehingga termotivasi untuk melakukan perubahan dalam penyampaian materi pembelajaran.

Learning artinya program yang dilaksanakan dapat membuat perubahan pengetahuan, sikap, dan keterampilan dari peserta bimtek. Oleh karena itu, untuk mengukur efektivitas bimtek, perlu adanya pengukuran terhadap ketiga aspek tersebut. Dari sisi pengetahuan, guru-guru sudah mampu membuat media pembelajaran interaktif menggunakan aplikasi KFM dan dibuktikan dengan produk media pembelajaran yang diserahkan guru kepada pemateri. Dari sisi sikap, sikap guru yang semula pesimis terhadap penggunaan media pembelajaran interaktif di kelas menjadi optimis karena munculnya rasa percaya diri guru untuk memanfaatkan IT dalam pembelajaran. Dari sisi keterampilan, kemampuan guru menggunakan komputer dan beberapa program pendukung pembuatan media pembelajaran interaktif semakin meningkat.

Setelah melakukan evaluasi keefektivan program bimbingan teknis tahap 1, tim PKM mengunjungi SMAN 2 Palembayan kembali dan mewawancarai beberapa orang guru. Pertanyaan yang diberikan seputar pembuatan media pembelajaran dan penerapannya di dalam kelas. Beberapa orang guru terutama bidang studi sains (Fisika, Kimia, Biologi) dan PAI sudah menerapkan aplikasi ini di kelas.

Adanya perubahan pola pembelajaran dengan menggunakan media, (sebelumnya tidak menggunakan media), membuat siswa SMAN 2 Palembayan lebih aktif dan bersemangat dalam kegiatan pembelajaran. Menurut Nurmayanti (2015), buku digital dinilai memiliki tampilan yang dinamis, disertai dengan animasi dan video yang dapat membuat siswa lebih aktif dalam kegiatan belajar. Hal ini selaras dengan hasil penelitian Rozy (2016) bahwa ebook 3D Pageflip yang dikembangkannya mendapatkan respon siswa dengan nilai rerata $92 \%$ dengan kategori "Sangat Baik". Selain itu, penelitian oleh Hidayatullah (2016) juga menunjukkan respon yang sangat baik terhadap media flipbook.

\section{KESIMPULAN}

Berdasarkan data hasil pengembangan media pembelajaran yang dilakukan oleh guru SMAN 2 Palembayan, didapatkan rata-rata skor bimtek senilai 75 dengan kategori cukup. Sebelum melaksanakan bimtek, hanya 12 dari 20 guru yang pernah membuat media dan 4 diantaranya berhasil membuat media pembelajaran interaktif. Artinya hanya 20\% guru SMAN 2 Palembayan yang berpengalaman dalam pembuatan media pembelajaran interaktif. Setelah melakukan bimtek, semua guru sudah mampu membuat media pembelajaran interaktif menggunakan aplikasi KFM.

\section{DAFTAR PUSTAKA}

Aqib, Zainal. (2013). Model-Model, Media, dan Strategi Pembelajaran Kontekstual. (Inovatif). Bandung : Yrama Widya

Arsyad, Azhar. (2002). Media Pembelajaran. Jakarta: Rajawali Pers.

Budiwibowo, Satrijo. (2014). Pengaruh Gaya Kepemimpinan Transaksional, Transforma sional dan Disiplin Kerja Terhadap Kinerja Guru (Karyawan) di Kota Madiun. Premiere Educandum, 4(2), 119 - 132.

Divayana, D.G.H. (2018). Pelatihan Pembuatan Buku Digital Berbasis Kvisoft Flipbook Maker Bagi Para Guru Di SMK TI Udayana. Jurnal Abdimas Dewantara, 1(2), 31-44.

Divayana, D.G.H., Suyasa, P.W.A., \& Sugihartini, N. (2016). Pengembangan Media Pembelajaran Berbasis Web Untuk Matakuliah Kurikulum dan Pengajaran di Jurusan Pendidikan Teknik Informatika Universitas Pendidikan Ganesha. Jurnal Nasional Pendidikan Teknik Informatika (JANAPATI), 5(3), 149-157.

Fadli, A., Suharno, S., \& Musadad, A. A. (2017). Deskripsi Analisis Kebutuhan Media Pembelajaran Berbasis Role Play Game Education untuk Pembelajaran Matematika. In Prosiding Seminar Nasional Teknologi Pendidikan.

Gomes, Faustino Cardoso. (2000). Managemen Sumber Daya Manusia. Edisi I. Yogyakarta, Andi Offset.

Hasanah, Lukman Nulhakim Umrotul. (2015). Pengembangan Media Pembelajaran Film Animasi sebagai Media Pembela jaran Konsep Fotosintesis. Jurnal Penelitian dan Pembelajaran IPA, 1(1), 91-106.

Hidayatullah, Muhammad Syarif. (2016). Pengembangan Media Pembelajaran Berba sis Flipbook Maker Pada Mata Pelajaran Elektronika Dasar di SMK Negeri 1 
Sampang. Jurnal Pendidikan Teknik Elektro, 5(1), 83-88.

Hosnan, M. (2014). Pendekatan Saintifik dan Kontekstual dalam Pembelajaran Abad 21. Bogor: Ghalia Indonesia.

Misbahudin. (2013). Analisis Data Penelitian dengan Statistik. Jakarta: Bumi Aksara Jakarta.

Mulyaningsih, N.N., \& Saraswati, D.L. (2017). Penerapan Media Pembelajaran Digital Book Dengan Kvisoft Flipbook Maker. Jurnal Pendidikan Fisika, 5 (1), 25-32.

Nurmayanti, Fitri, Fauzi Bakri dan Esmar Budi. (2015). Pengembangan Modul Elektro nik Fisika dengan Strategi PDEODE pada Pokok Bahasan Teori Kinetik Gas untuk Siswa Kelas XI SMA. Prosiding Simposium Nasional Inovasi dan Pembelajaran Sains 2015. Bandung

Nuroifah, N. (2015). Pengembangan Media Pembelajaran Berbasis Aplikasi Android Materi Sistem Ekskresi Siswa Kelas XI SMAN1 Dawarblandong Mojokerto. Jurnal Mahasiswa Teknologi Pendidikan, 1(1).

Permanasari, Anna. (2016). STEM Education: Inovasi dalam Pembelajaran Sains. Prosiding Seminar Nasional Pendidikan Sains (SNPS)

Rahim, Fanny Rahmatina et al. (2017). Studi Pengalaman Guru-Guru MTsN 6 Pesisir Selatan Dalam Penulisan Karya Tulis Ilmiah Guna Meningkatan Iptek Masyarakat Serta Mewujudkan Guru yang Profesional. Jurnal Eksakta Pendidikan (Jep), [S.1.], v. 1, n. 2, p. 80-87, dec. 2017. ISSN 2579-860X.

Rahim, Fanny Rahmatina. (2018). Research Based Learning dalam Pembelajaran IPA Terpadu untuk Meningkatkan Kemampuan Berpikir Kreatif Mahasiswa. SEMESTA: Journal of Science Education and Teaching, [S.1.], v.1, n.2, p.32-38, dec. ISSN 25981951.

Rahim, Fanny Rahmatina. (2019a). Implemen tasi Research Based Learning (RBL) pada Mata Kuliah IPA Terpadu di Pro-gram Studi Pendidikan Fisika. Jurnal Eksakta Pendidikan (JEP), [S.1.], v.3, n.1, p.82-91, May 2019. ISSN 2579-860X.

Rahim, F R et al. (2019b). A Preliminary Investigation Into Critical and Creative Thinking Skills of University Students in Integrated Science Class 7 Course. Journal of Physics: Conference Series. 1185012131

doi:10.1088/1742-596/1185/1/012131.

Rizki, Swaditya. (2016). Pengembangan Bahan Ajar Program Linear Berbasis Kontekstual dan Ict. AKSIOMA: Jurnal Program Studi Pendidikan Matematika, 5(2), 137-144.

Rozy, Adam Fatchur dan Yuda Anggana A. (2016). Pengembangan Media Pembelajaran Elektronika Berbasis 3d Pageflip pada Mata Pelajaran Penerapan Rangkaian Elektronika di SMK Negeri 1 Kediri. Jurnal Pendidikan Teknik Elektro Unesa, 6(1), 1-7.

Rusman, Deni Kurniawan. (2012). Pembelajaran Berbasis Teknologi dan Informasi. Jakarta: PT. Raja Grafindo Persada

Sanjaya, Wina. (2006). Strategi Pembelajaran Berorientasi Standar Proses Pendidikan. Bandung: Kencana.

Seamardi. (2016). Penerapan Inovasi Flipbook sebagai Media Pembelajaran untuk Meningkatkan hasil belajar Pengenalan PHP Kelas XI RPL di SMKN 2 Mojokerto. Jurnal IT-Edu, 1(2), 2016, ISSN 25409263.

Sugianto, D., Abdullah, A.G., Elvyanti, S., \& Muladi, Y. (2013). Modul Virtual: Multimedia Flipbook Dasar Teknik Digital. INVOTEC, 9(2), 101-116.

Sugiharni, G.A.D. (2018). Pengembangan Modul Matematika Diskrit Berbentuk Digital Dengan Pola Pendistribusian Asyn chrnous Menggunakan Teknologi Open Source. Jurnal Nasional Pendidikan Teknik Informatika (JANAPATI), 7(1), 58-72.

Sugiyono. (2011). Metode Penelitian Pendidikan (Pendekatan Kuantitatif, Kualitatif, dan R\&D). Bandung: Alfabeta.

Sugiyono. (2012). Metode Penelitian Kuantitatif Kualititatif dan R\&D. Bandung: Alfabeta.

Suryadi. (2007). Pemanfaatan ICT Dalam Pembelajaran. Jurnal Pendidikan Terbuka dan Jarak Jauh, 8(1), 83-98, e-ISSN 24422266.

Suwardana, Hendra. (2017). Revolusi Industri 4.0 Berbasis Revolusi Mental. JATI UNIK, $1(2), 102-110$.

Suyanto. (2006). Dinamika Pendidikan Nasional (dalam Percaturan Dunia Global). Jakarta: PSAP Muhammadiyah.

Undang-Undang Nomor 20 Tahun 2003 tentang Sistem Pendidikan Nasional 